Article

\title{
Eco-Physiological Traits and Phenylpropanoid Profiling on Potted Vitis vinifera L. cv Pinot Noir Subjected to Ascophyllum nodosum Treatments under Post-Veraison Low Water Availability
}

\author{
Linda Salvi ${ }^{1}\left(\mathbb{D}\right.$, Cecilia Brunetti ${ }^{1,2}, *\left(\mathbb{D}\right.$, Eleonora Cataldo ${ }^{1}$, Paolo Storchi ${ }^{3}(\mathbb{D}$ and \\ Giovan Battista Mattii ${ }^{1}$ (D) \\ 1 Department of Agriculture, Food, Environment and Forestry (DAGRI), University of Florence, \\ 50019 Sesto Fiorentino, Florence, Italy; linda.salvi@unifi.it (L.S.); eleonora.cataldo@unifi.it (E.C.); \\ giovanbattista.mattii@unifi.it (G.B.M.) \\ 2 Institute for Sustainable Plant Protection (IPSP), National Research Council of Italy, 50019 Sesto Fiorentino, \\ Florence, Italy \\ 3 Council for Agricultural Research and Economics, Research Centre for Viticulture and Enology (CREA-VE), \\ 52100 Arezzo, Italy; paolo.storchi@crea.gov.it \\ * Correspondence: cecilia.brunetti@ipsp.cnr.it; Tel.: +39-055-4574024
}

Received: 28 May 2020; Accepted: 25 June 2020; Published: 28 June 2020

check for updates

\begin{abstract}
In Mediterranean regions, extreme weather conditions during the growing season may alter grapevine physiology and metabolism, thus modifying the quality of wines. The objective of this study was to investigate the effects of Ascophyllum nodosum treatments on plant physiology and berry metabolism in Vitis vinifera exposed to water stress. The experiment was performed on potted vines subjected to two irrigation regimes (well-watered, WW, and water stressed, WS) both associated with A. nodosum treatments (SWE), compared with control plants (CTRL). Gas exchanges, chlorophyll fluorescence, and water relations were monitored on SWE and CTRL leaves, both in WW and WS vines at three times. Moreover, the quantification of secondary metabolites and their partitioning were performed in berry skins. Plants treated with A. nodosum extract showed higher photosynthesis and stomatal conductance than CTRL in both irrigation regimes and maintained a better plant hydraulic conductivity at the end of the sampling period. In addition, secondary metabolites in berry skins and their partitioning were significantly affected by the treatments in both irrigation regimes. Our results suggest that foliar application of $A$. nodosum extract may help the acclimation of grapevines to post-veraison water stress, likely improving plant physiological and biochemical performances under environmental constraints.
\end{abstract}

Keywords: biostimulants; abiotic stress; climate change; drought; water potential; gas exchanges; berry skin metabolites; enzymatic activity; phenylpropanoid pathway

\section{Introduction}

Soil water deficit is the main environmental constraint for viticulture in the Mediterranean basin [1,2]. Climate projections for this area predict changes in rainfall and seasonal temperature patterns in the next decades, with a higher frequency of extreme climate events [3,4]. These future trends due to global climate change are expected to negatively affect grapevine physiology and grape quality.

Stomatal closure is one of the first responses to drought. It is widely reported that the reduction in carbon fixation due to stomatal limitations is the crucial issue for grapevine performances under 
mild drought, as indicated by increased water use efficiency (WUE, i.e., the ratio of photosynthesis to transpiration) [5-10]. For more prolonged and/or more pronounced water deficits leading to decrease of stomatal conductance $\left(g_{\mathrm{s}}\right)$ below $50 \mathrm{mmol} \mathrm{H}_{2} \mathrm{O} \mathrm{m}^{-2} \mathrm{~s}^{-1}$, photosynthetic limitations becomes more dependent on nonstomatal processes, especially decreased mesophyll conductance to $\mathrm{CO}_{2}$ and impaired photochemistry [11,12]. Moreover, abiotic stresses, such as drought and high temperatures, influence the primary and secondary metabolism thus accelerating phenological stages (i.e., budburst, flowering, and veraison) and berry ripening [13]. In particular, the synthesis of phenolic compounds and aromatic ripeness in berry skin are delayed, while total sugars increase, thus resulting in wine with low acidity and high alcohol concentration [14-16]. In grape berries, the most abundant polyphenol subclasses are flavonols and anthocyanins [17]. These phenols are especially responsible for stability to oxidation, color, and flavor of wines [18-20]. The total amount of anthocyanins and the relative abundance of single anthocyanins are under genetic control [21]. This means that all cultivars express functional genes coding for enzymes that lead to the biosynthesis of di-hydroxylated (peonidin and cyanidin) or tri-hydroxylated (delphinidin, petunidin, and malvidin) anthocyanins as well as to the methylation of primary anthocyanins. Harsh environmental conditions, such as water shortage, high radiations, and hot temperatures, interacting with genotype, boost the shift of cyanidin and delphinidin (hydroxylated anthocyanins) into their methoxylated counterparts, namely peonidin, petunidin, and malvidin [22,23].

Hence, the cultivation of grapevines in a climate change scenario might require a selection of sustainable management practices to maintain grape quality under the future environmental constraints, like the foliar application of biostimulants [24-26]. Many studies have reported the ability of Ascophyllum nodosum-based biostimulants to promote plant growth, yield, and fruit quality [27-29] and to enhance the tolerance of grasses and crops to drought events [30-35]. This broad effectiveness may be ascribed to the high concentration of amino acids found in the Ascophyllum-based extracts, which may act as compatible solutes under osmotic stress [36,37], as well as to the presence of bioactive secondary metabolites such as vitamins and their precursors [38,39], that may protect plant tissues against stress-induced reactive oxygen species (ROS) [40]. If compared to the published research on the effects of $A$. nodosum applications on the yield of table grapes [41-44], only a few studies have focused on grapevines responses to abiotic stresses [45,46] and on berry composition [46-50] following seaweed extract treatments. In a previous two-year field experiment, Salvi et al. [46] demonstrated an improvement of gas exchanges and grape maturity balance, induced through the application of A. nodosum treatments on the phenylpropanoid pathway. Although these results supported the potential effect of $A$. nodosum in promoting the biosynthesis of anthocyanins and improving water stress tolerance in vines, further experimental evidences conducted under drought controlled conditions are needed to validate these hypotheses. In addition, although considerable evidences are available [46,50], the effect on $A$. nodosum-treated plants phenylpropanoid pathway is currently unclear and only hypothesized.

For these reasons, the aims of this study were (1) to test if $A$. nodosum extract treatments were able to positively affect grapevine physiology promoting higher tolerance to drought in controlled conditions; and (2) to validate the effect on berry phenylpropanoid metabolism, investigating the activity of the enzymes involved in the pathway.

In order to achieve these goals and validate the previous results reported in Salvi et al. [46], the comparison between vines treated with $A$. nodosum extract and nontreated ones was set up on Pinot noir $\mathrm{cv}$. (Vitis vinifera L.) potted vines subjected to two irrigation regimes, integrating physiological and metabolic measurements.

\section{Materials and Methods}

\subsection{Experiment Location and Plot Settings}

This study was conducted for one growing season (2017) on 11-year-old homogeneous potted vines (average number of leaves/vine 103.5; average shoot length after topping $73.2 \mathrm{~cm}$; average canopy 
leaf area/vine $1.13 \mathrm{~m}^{2}$ ) (Vitis vinifera) of cv. Pinot noir (clone Entav 115), grafted on 1103 Paulsen rootstock and grown outdoor at CREA-VE, Arezzo, Italy (Lat. $43.476^{\circ} \mathrm{N}$, Long. $11.824^{\circ} \mathrm{E} ; 260 \mathrm{~m}$ a.s.1.). Pots $(70 \mathrm{~L})$ were filled with a clay-loam soil with the following average characteristics: clay $40 \%$; silt $35 \%$; and sand $25 \%$, with a volumetric soil water content of $\sim 34 \%$ at field capacity, collected from a vineyard of the Chianti Classico D.O.C.G. district in Tuscany, Italy [51]. The vines were trained on vertical shoot positioned trellis, with spur cordon pruning and an average of 10 buds per vine. Every year, at the end of February, each container was fertilized with $40 \mathrm{~g}$ of controlled-release fertilizer (Nitrophoska, 12N-12P-17K, Eurochem Agro, Cesano Maderno (MB), Italy). To avoid excessive soil over warming, which can negatively affect roots, and maintain a stable temperature, pots were protected by wrapping their lateral surface with a shade net.

At the beginning of the experiment (veraison, modified Eichorn and Lorenz (E-L) stage 35; 13 July 2017), 20 plants were maintained at $90 \%$ of maximum water availability as controls (WW, well-watered vines) until harvest (E-L stage 38), while the other 20 plants were subjected to a water deficit at $40 \%$ of maximum water availability (WS, water-stressed) [52]. The water regime was imposed later in the season, because post-veraison water deficit tends to have greater effects on berry ripening as compared to pre-veraison stress, which, conversely, affects primarily berry size [53]. Until the beginning of treatment, all plants were maintained at field capacity. During water limitation, the surface of the plant containers was covered with aluminum foils to avoid rainfall interference and to minimize soil water evaporation. The water supply per pot was determined monitoring the soil moisture, as volumetric content, by time domain reflectometry using Trase System 1 (Soil Moisture Equipment Corporation, Goleta, CA, USA). Readings were taken every day in the early morning with $30 \mathrm{~cm}$ long electrodes located in the pots. In each pot, water was supplied at 2 day intervals with drip irrigation emitters.

During the differential irrigation period, ten of the WW vines and ten of the WS ones were treated twice with $3 \mathrm{~g} / \mathrm{L}$ of a noncommercial A. nodosum extract (SWE) $[35,46,49]$. This extract is mainly rich in amino acids, among which the most abundant were alanine, phenylalanine, proline, and methionine. A full extract characterization was provided in Salvi et al. [46]. The first application was performed approximately 20 days before the expected harvest (E-L stage $36 ; 27$ July 2017) and another one was repeated after 14 days (E-L stage 37; 10 August 2017) on the same plants. On the same days, the other ten vines of WW and ten vines of WS were sprayed with the same amount of water (CTRL).

At three stages, on 10 vines/treatment, berries samplings and eco-physiological measurements were conducted: $\mathrm{t}_{0}$ (before $A$. nodosum treatments and one week after irrigation regimes differentiation; E-L stage 36; 20 July 2017), $\mathrm{t}_{1}$ (7 days after the first $A$. nodosum treatment; E-L stage 37; 3 August 2017), and $\mathrm{t}_{2}$ (7 days after the second A. nodosum treatment; E-L stage 38; 17 August 2017).

\subsection{Climate Parameters}

Daily values of mean, minimum, and maximum air temperatures $\left({ }^{\circ} \mathrm{C}\right)$ and global radiation $\left(\mathrm{Wm}^{-2}\right)$ values were recorded using a meteorological station (Ecotech, Bonn, Germany) nearby.

\subsection{Leaf Gas Exchange, Chlorophyll Fluorescence, Leaf Water Potential, and Content}

At $t_{0}, t_{1}$, and $t_{2}$, net photosynthesis $\left(P_{n}\right)$, stomatal conductance $\left(g_{s}\right)$, and transpiration rate $(\mathrm{E})$ were measured on ten fully developed and intact leaves per treatment (one each vines, 10 replicates) using a portable infrared gas analyzer (model Ciras 3, PP Systems, Amesbury, MA, USA).

Measurements were carried out at ambient light intensity $\left(1300 \mu \mathrm{mol} \mathrm{m} \mathrm{m}^{-2} \mathrm{~s}^{-1}\right)$ and ambient $\mathrm{CO}_{2}$ concentration (400 ppm). Water use efficiency (WUE) was calculated as the ratio of photosynthesis to transpiration. The maximum quantum yield of photosystem II (PSII) photochemistry $\left(\mathrm{F}_{\mathrm{v}} / \mathrm{F}_{\mathrm{m}}\right)$ was recorded with a portable fluorometer (Handy-PEA ${ }^{\circledR}$, Hansatech Instruments, King's Lynn, UK) on the same leaves used for gas exchanges at $t_{0}, t_{1}$, and $t_{2}$. Then, $F_{v} / F_{m}$ was calculated as Maxwell and Johnson [54]. At the same stages, leaf predawn ( $\left.\Psi_{\mathrm{pd}}, \mathrm{MPa}\right)$ and leaf ( $\left.\Psi_{\text {leaf }}, \mathrm{MPa}\right)$ and stem midday $\left(\Psi_{\text {stem }}, \mathrm{MPa}\right)$ water potentials were determined following Scholander et al. [55] with a pressure chamber (model 600, PMS Instrument Co., Albany, OR, USA). $\Psi_{\text {pd }}$ was measured between 04.00 and $05.00 \mathrm{~h}$ on 
ten fully expanded leaves per treatment, whereas $\Psi_{\text {leaf }}$ and $\Psi_{\text {stem }}$ were measured at 12 p.m. on the same leaves used for leaf gas exchange measurements (leaves over 60-min dark-adapted for $\Psi_{\text {stem }}$ ). The whole-plant hydraulic conductance $\left(\mathrm{K}_{\text {plant }}\right)$, expressed as the relationship between the plant water loss by transpiration and the water potential drop from roots to leaves was calculated as $\mathrm{K}_{\text {plant }}=$ $\mathrm{E} /\left(\Psi_{\mathrm{pd}}-\Psi_{\text {leaf }}\right)[56,57]$. Other 10 leaves per-treatment were taken to calculate relative water content $(\mathrm{RWC}$, as $\mathrm{RWC}=((\mathrm{FM}-\mathrm{DM}) /(\mathrm{TM}-\mathrm{DM})) \times 100$ where $\mathrm{FM}, \mathrm{TM}$, and DM denote fresh, turgid, and dry masses, respectively).

\subsection{Grape Composition and Yield}

At $t_{0}, t_{1}$, and $t_{2}$, a sample of 50 berries/vine was picked from the clusters of 10 vines (10 berry samples per treatment), weighed (PCE Italia s.r.l digital scale, Capannori (LU), Italy), and juiced. Total sugars ( $\left({ }^{\circ}\right.$ Brix) were determined with a refractometer (ATAGO, Bellevue, WA, USA). Titratable acidity (TA, $\mathrm{gL}^{-1}$ tartaric acid) was measured on a $10 \mathrm{~mL}$ sample by manual glass burette, titrating with $0.1 \mathrm{M}$ $\mathrm{NaOH}$ to an end point of $\mathrm{pH}$ 7.0. Juice $\mathrm{pH}$ was measured using a portable $\mathrm{pH}$ meter (Hanna instrument, Woonsocket, RI, USA). At harvest $\left(t_{2}\right)$, clusters from 10 vines/treatment were picked, computed, and weighed with a portable electronic scale (Bonso Advanced Technology Ltd., Hong Kong, China) to obtain cluster weight $(\mathrm{g})$ and yield per vine $(\mathrm{kg})$.

\subsection{Berry Skin Phenylpropanoids}

At $t_{0}, t_{1}$, and $t_{2}$, flavonol, hydroxycinnamic acid, and anthocyanin contents were determined in berry skins ( 5 samples/treatment, each composed by a pool of 30 berries collected from 2 of the 10 vines/treatment). The samples were collected randomly within the clusters of the same vine at each sampling time, also assuming that all the vines of the same treatment and irrigation regime were at the same developmental stage. After freezing berry samples in liquid nitrogen, skins were peeled and lyophilized (Lio-5P, Cik solution, Karlsruhe, Germany), then, phenylpropanoid contents were detected with the same protocol of extraction, calibration, and quantification reported in Salvi et al. [46] and expressed as $\mu \mathrm{mol} \mathrm{g}{ }^{-1}$ of dry weight (DW). Briefly, $0.7 \mathrm{~g} / \mathrm{sample}$ of lyophilized berry skin were ground in a mortar and extracted with $75 \%$ of aqueous ethanol acidified to $\mathrm{pH} 2$ by $\mathrm{HCOOH}(3 \times 5 \mathrm{~mL})$. The supernatant was partitioned with $3 \times 5 \mathrm{~mL}$ of n-hexane, the extracts were added together and reduced to dryness under vacuum, then rinsed with $\mathrm{MeOH} / \mathrm{H}_{2} \mathrm{O}(50 / 50, \mathrm{pH} 2)$. The analytical determinations were conducted using a liquid chromatograph equipped with a quaternary 200Q/410 pump and an LC 200 diode array detector (DAD) (all from Perkin Elmer, Waltham, MA, USA). Individual anthocyanins and flavonols were quantified at 530 and $330 \mathrm{~nm}$, respectively, using calibration curves of authentic standards (Extrasynthese, Genay, France).

In order to investigate how SWE treatments affected anthocyanin composition, the percentage of methoxylated anthocyanins on total amount of 3-glucoside anthocyanins and the ratio of methoxylated to nonmethoxylated derivatives were estimated by the individual anthocyanin content.

Moreover, in order to compare the global balance of the biosynthesis generating anthocyanins in SWE and CTRL berries in both irrigation regimes, three key enzymatic activities, flavonoid $3^{\prime}, 5^{\prime}$-hydroxylase $\left(\mathrm{F}^{\prime} 5^{\prime} \mathrm{OH}\right), 3^{\prime}$-O-methyltransferase ( $3^{\prime}$-OMT), and $5^{\prime}$-O-methyltransferase (5'-OMT), linked to known structural genes involved in the synthesis of anthocyanins, were investigated following Mattivi et al. [19].

\subsection{Statistical Analysis}

To compare A. nodosum treatments effects in different irrigation regimes and factors interactions, all data were subjected to a two-way analysis of variance $(p \leq 0.05)$ using SPSS Statistic 25 (IBM, Endicott, NY, USA).

The two irrigation regimes (WW and WS) were combined with A. nodosum treatments (SWE and CTRL) and supposed as fixed factors. 
After running preliminary Shapiro-Wilk's $(p \leq 0.05)$ and Levene's $(p \leq 0.05)$ tests to verify the normal distribution and the homogeneity of variance of each dataset, since the purpose of this study was to elucidate the effects of $A$. nodosum treatments on grapevine physiology, berry phenylpropanoid metabolism and drought stress tolerance, factor significant interactions were checked also with one-way ANOVA $(p \leq 0.05)$ and reported in figures and tables. Mean values were separated by Fisher's least significant difference (LSD) post-hoc test $(p \leq 0.05)$. Linear regression analysis was performed to assess possible relationships between $\Psi_{\mathrm{pd}}$ and $\Psi_{\text {leaf }}$ using Sigmaplot (Systat Software Inc., San Jose, CA, USA).

\section{Results}

The Shapiro-Wilk's test output values and the visual inspection of histograms and box plots showed that each dataset was approximately normally distributed. Skewness and kurtosis values of each parameter were reported in Supplementary Table S3. Moreover, the Levene's test verified the equality of variances in the samples.

\subsection{Climate Parameters}

The 2017 microclimate conditions of the experimental area are reported in Figure 1.

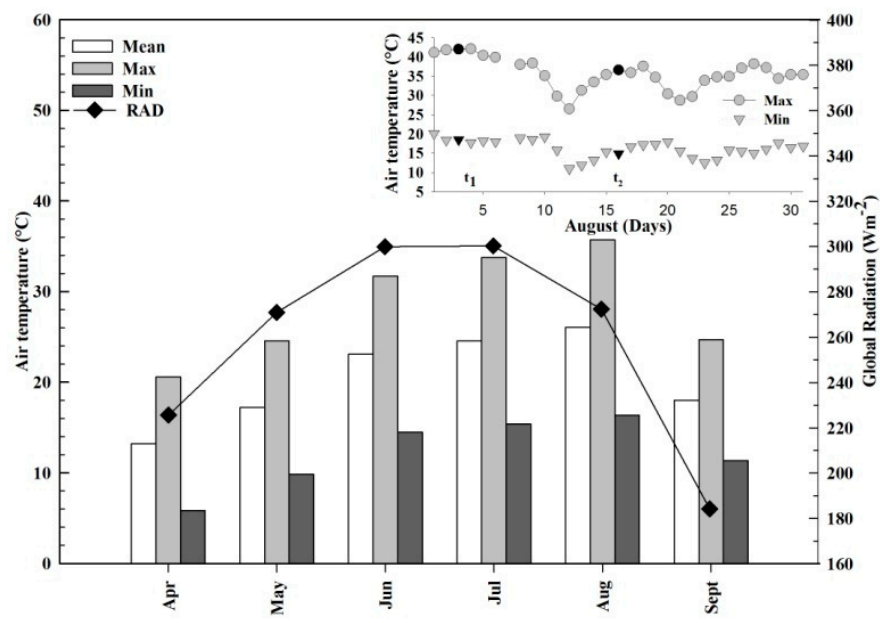

Figure 1. Climate parameters of the experiment location. Monthly averages of mean, maximum, and minimum air temperature $\left({ }^{\circ} \mathrm{C}\right)$ and global radiation $\left(\mathrm{RAD}, \mathrm{W} \mathrm{m}^{-2}\right)$ measured from April to September; in the inset the daily averages of maximum and minimum air temperature $\left({ }^{\circ} \mathrm{C}\right)$ measured in August are shown.

Average mean, maximum, and minimum air temperatures, measured from bud break to leaf fall (April-September), were $19.5^{\circ}, 27.5^{\circ}$, and $11.4{ }^{\circ} \mathrm{C}$, respectively. The most torrid month of this period was August (maximum temperatures were always above $40^{\circ} \mathrm{C}$ in the firsts five days of this month). The hottest day was the $3 \mathrm{rd}$ of August (corresponding to $t_{1}$ for eco-physiological measurements and berries samplings), when maximum and minimum air temperatures were $+2^{\circ}$ and $+6^{\circ}$ higher, respectively, than the corresponding monthly averages.

\subsection{Leaf Gas Exchange, Chlorophyll Fluorescence, and Leaf and Stem Water Potential}

All eco-physiological parameters of SWE and CTRL plants in both irrigation regimes resulted similar at $\mathrm{t}_{0}$, because at this stage treatments with $A$. nodosum were not performed yet and only the differential irrigation regimes were applied (Table 1).

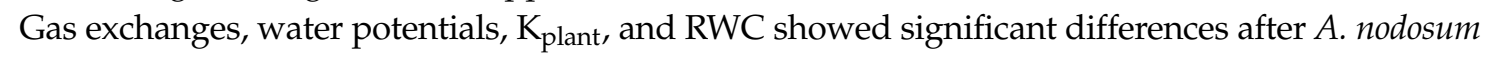
treatments and irrigation regime differentiation, whereas a statistical difference was not detected in $\mathrm{F}_{\mathrm{v}} / \mathrm{F}_{\mathrm{m}}$. Lower values of $P_{n}, g_{s}$, WUE, $\Psi_{\mathrm{pd}}, \Psi_{\text {stem }}$, and $\mathrm{K}_{\text {plant }}$ were observed in WS than in WW vines (Table 2). 
Table 1. Leaf gas exchanges and chlorophyll fluorescence in V. vinifera treated with A. nodosum extract (SWE) and untreated plants (CTRL), under two irrigation regimes (WW, well-watered; WS, water stressed).

\begin{tabular}{|c|c|c|c|c|c|c|c|c|c|}
\hline \multirow[b]{2}{*}{ Irrig. Regime } & \multirow[b]{2}{*}{ Samp. Time } & \multicolumn{2}{|c|}{$P_{n}\left(\mu \mathrm{mol} / \mathrm{m}^{2} \mathrm{~s}\right)$} & \multicolumn{2}{|c|}{$g_{s}\left(\mathrm{mmol} / \mathrm{m}^{2} \mathrm{~s}\right)$} & \multicolumn{2}{|c|}{$\mathrm{F}_{\mathrm{v}} / \mathrm{F}_{\mathrm{m}}$} & \multicolumn{2}{|c|}{ WUE $\left(\mathrm{mmol} / \mathrm{m}^{2} \mathrm{~s}\right)$} \\
\hline & & CTRL & SWE & CTRL & SWE & CTRL & SWE & CTRL & SWE \\
\hline \multirow{3}{*}{ WW } & $\mathrm{t}_{0}$ & $13.9 \pm 0.7 \mathrm{a}$ & $15.0 \pm 1.5 \mathrm{a}$ & $162.2 \pm 19.6 \mathrm{a}$ & $146.1 \pm 9.3 \mathrm{a}$ & $0.77 \pm 0.01 \mathrm{a}$ & $0.77 \pm 0.01 \mathrm{a}$ & $3.4 \pm 0.4 \mathrm{a}$ & $3.5 \pm 0.4 \mathrm{a}$ \\
\hline & $t_{1}$ & $6.6 \pm 0.6 \mathrm{a}$ & $8.6 \pm 0.5 a$ & $94.4 \pm 3.4 \mathrm{a}$ & $92.8 \pm 5.4 \mathrm{a}$ & $0.76 \pm 0.02 a$ & $0.78 \pm 0.01 \mathrm{a}$ & $4.9 \pm 0.2 \mathrm{a}$ & $3.7 \pm 0.2 \mathrm{~b}$ \\
\hline & $t_{2}$ & $6.6 \pm 1.9 \mathrm{~b}$ & $11.6 \pm 0.7 \mathrm{a}$ & $86.0 \pm 14.7 \mathrm{~b}$ & $161.5 \pm 12.6 \mathrm{a}$ & $0.80 \pm 0.01 \mathrm{a}$ & $0.77 \pm 0.03 a$ & $2.6 \pm 0.7 \mathrm{a}$ & $2.6 \pm 0.1 \mathrm{a}$ \\
\hline \multirow{3}{*}{ WS } & $t_{0}$ & $4.8 \pm 1.1 \mathrm{a}$ & $5.3 \pm 2.3 \mathrm{a}$ & $92.4 \pm 14.8 \mathrm{a}$ & $82.2 \pm 12.4 \mathrm{a}$ & $0.77 \pm 0.01 \mathrm{a}$ & $0.77 \pm 0.01 \mathrm{a}$ & $1.8 \pm 0.5 \mathrm{a}$ & $1.0 \pm 0.5 \mathrm{a}$ \\
\hline & $t_{1}$ & $8.1 \pm 0.4 \mathrm{a}$ & $7.0 \pm 0.6 \mathrm{a}$ & $62.3 \pm 3.4 \mathrm{a}$ & $62.2 \pm 6.4 \mathrm{a}$ & $0.73 \pm 0.03 a$ & $0.76 \pm 0.02 \mathrm{a}$ & $4.6 \pm 0.4 \mathrm{a}$ & $3.4 \pm 0.1 b$ \\
\hline & $t_{2}$ & $1.0 \pm 0.2 \mathrm{~b}$ & $4.3 \pm 1.1 \mathrm{a}$ & $18.2 \pm 5.0 \mathrm{~b}$ & $49.5 \pm 11.4 \mathrm{a}$ & $0.80 \pm 0.01 \mathrm{a}$ & $0.80 \pm 0.01 \mathrm{a}$ & $1.1 \pm 0.4 b$ & $2.1 \pm 0.3 a$ \\
\hline
\end{tabular}

Means $( \pm \mathrm{SE}, n=10)$ followed by distinct letters within the same parameter and row are significantly different according to the LSD test $(p \leq 0.05)$. Measurements were conducted at $\mathrm{t}_{0}, \mathrm{t}_{1}$, and $t_{2}$

Table 2. Two-way ANOVA $(p<0.05)$ for eco-physiology, chemical features of the berry and productivity parameters in $V$. vinifera treated with $A$. nodosum extract (SWE) and untreated plants (CTRL), under two irrigation regimes (WW, well-watered; WS, water stressed).

\begin{tabular}{|c|c|c|c|c|c|c|c|c|c|c|c|c|}
\hline Parameter & $P_{n}$ & $g_{s}$ & E & WUE & $\Psi_{\mathrm{pd}}$ & $\Psi_{\text {stem }}$ & RWC & $K_{\text {plant }}$ & TA & $\begin{array}{c}\text { Berry } \\
\text { Weight }\end{array}$ & $\begin{array}{l}\text { Cluster } \\
\text { Weight }\end{array}$ & Yield/Vine \\
\hline Unit & $\mathrm{mol} \mathrm{m}^{-2} \mathrm{~s}^{-1}$ & $\mathrm{mmol} \mathrm{m} \mathrm{m}^{-2} \mathrm{~s}^{-1}$ & $\mathrm{mmol} \mathrm{m}^{-2} \mathrm{~s}^{-2}$ & $\mathrm{Mmol} \mathrm{m}^{-2} \mathrm{~s}^{-2}$ & MPa & MPa & $\%$ & $\mathrm{mmol} \mathrm{MPa}^{-1} \mathrm{~s}^{-1} \mathrm{~m}^{-2}$ & $\mathrm{gL}^{-1}$ & $\mathrm{~g}$ & g & $\mathrm{g}$ \\
\hline \multicolumn{13}{|l|}{ Treatments } \\
\hline Treated & 8.9152 & 111.0000 & 3.2707 & 2.7552 & -0.6176 & -1.2872 & 73.5383 & 3.24 & 10.4737 & 0.6873 & 52.4 & 312.1 \\
\hline Nontreated & 8.1578 & 95.2000 & 2.8696 & 2.8891 & -0.7547 & -1.4238 & 68.6305 & 2.50 & 10.6412 & 0.6852 & 46.1 & 276.7 \\
\hline \multicolumn{13}{|l|}{ Irrig. Regime } \\
\hline WW & 11.73 & 133.32 & 3.73 & 3.33 & -0.43 & -1.10 & 70.43 & 3.52 & 12.46 & 0.75 & 51.72 & 312.00 \\
\hline WS & 5.13 & 71.00 & 2.37 & 2.28 & -0.95 & -1.63 & 71.68 & 2.22 & 9.34 & 0.58 & 46.81 & 289.79 \\
\hline \multicolumn{13}{|l|}{ Significance } \\
\hline Treatments & 0.512 & 0.039 & 0.019 & 0.387 & 0.017 & 0.035 & 0.020 & 0.042 & 0.874 & 0.001 & 0.606 & 0.459 \\
\hline Irrig. Regime & 0.000 & 0.000 & 0.000 & 0.000 & 0.000 & 0.000 & 0.506 & 0.025 & 0.005 & 0.000 & 0.031 & 0.018 \\
\hline Treat. $\times$ Irrig. Regime & 0.500 & 0.634 & 0.646 & 0.002 & 0.005 & 0.003 & 0.967 & 0.011 & 0.571 & 0.041 & 0.694 & 0.412 \\
\hline
\end{tabular}

Values are the mean of each parameter, considering treatments and irrigation regime (Irrig. Regime) as factors. In the last 3 rows is indicated the significance. Other abbreviations: net assimilation rate $\left(P_{n}\right)$, stomatal conductance $\left(g_{s}\right)$, transpiration (E), water use efficiency (WUE), predawn water potential $\left(\Psi_{\mathrm{pd}}\right)$, midday stem water potential $\left(\Psi_{\text {stem }}\right)$, relative water content (RWC), and total acidity (TA). 
At $\mathrm{t}_{1}$, similar values of $P_{n}$ and $g_{s}$ were observed in SWE than CTRL in both WW and WS vines. At $t_{2}$, in well-watered vines, SWE plants showed significant higher values of $P_{n}$ and $g_{s}$ than CTRL plants, whereas WUE was largely unaffected by A. nodosum treatments. At the same sampling time, water stressed SWE vines were able to maintain significant higher levels of $P_{n}, g_{s}$, and WUE than corresponding CTRL vines (Table 1).

At $t_{1}, \Psi_{\mathrm{pd}}$ and $\Psi_{\text {stem }}$ were largely unaffected by A. nodosum treatments in WW plants (Figure 2A,B). On the contrary, under water stress conditions, both at $t_{1}$ and $t_{2}$, SWE vines displayed higher $\Psi_{p d}$ and

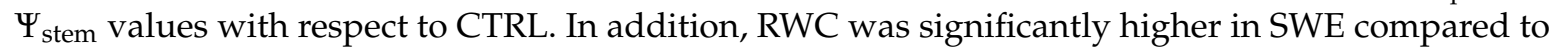
CTRL vines at $t_{1}$ (first week of August) only in WS vines (Figure 2C). At $t_{2}$, RWC and $K_{\text {plant }}$ values were significantly higher in SWE than CTRL in both water regimes (Figure $2 \mathrm{C}, \mathrm{D}$ ). $\mathrm{F}_{\mathrm{v}} / \mathrm{F}_{\mathrm{m}}$ did not show significant changes after $A$. nodosum treatments.

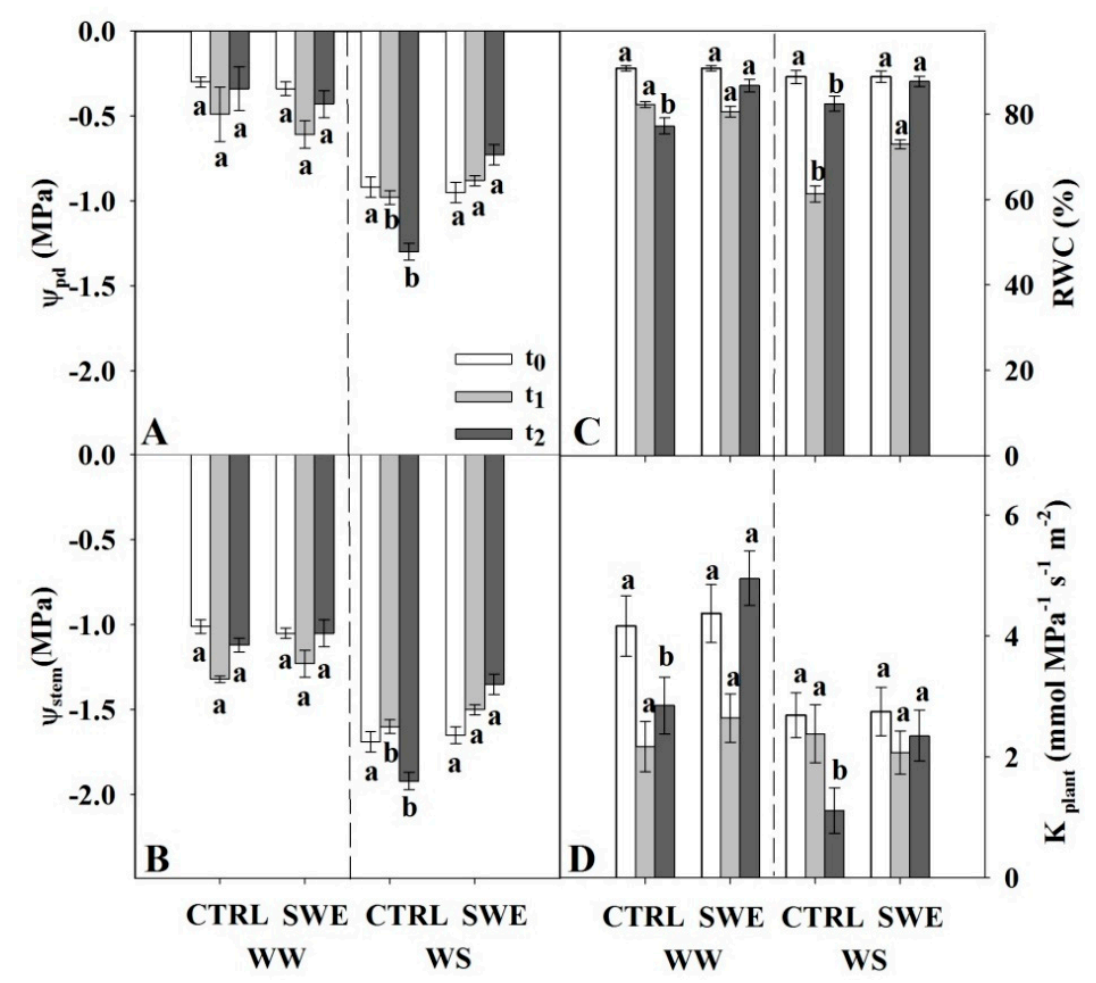

Figure 2. (A) Predawn $\left(\Psi_{\mathrm{pd}}\right)$ and (B) midday stem $\left(\Psi_{\text {stem }}\right)$ water potentials, $(C)$ relative water content (RWC), and (D) plant hydraulic conductivity ( $\left.\mathrm{K}_{\text {plant }}\right)$ in V. vinifera treated with A. nodosum extract (SWE) and untreated plants (CTRL), under two irrigation regimes (WW, well-watered; WS, water stressed). Means $( \pm \mathrm{SE}, n=10)$ followed by distinct letters within the same water regime and sampling time are significantly different according to the LSD test $\left(p \leq 0.05\right.$ ). Measurements were conducted at $\mathrm{t}_{0}$ (white bar), $t_{1}$ (grey bar), and $t_{2}$ (dark grey bar)

A strong linear relationship was found between $\Psi_{\text {pd }}$ and $\Psi_{\text {leaf }}$, considering A. nodosum treated and untreated vines under both irrigation regimes $\left(R^{2}=0.97\right.$ and $\left.p<0.001\right)$ (Supplementary Figure S2).

\subsection{Grape Composition and Yield}

Irrigation regime induced significant differences $(p \leq 0.05)$ in berry weight, $\mathrm{pH}$, and titratable acidity (Table 2). Berry weight, $\mathrm{pH}$, and titratable acidity were $+29 \%,+6 \%$, and $+33 \%$ higher in $\mathrm{WW}$ than in WS vines, respectively (Table 2). Consequently, significant differences induced by irrigation regimes were also observed in cluster weight and yield/vine (Table 2). A. nodosum treatments did not induce significant effects in berry composition and productivity parameters in both water regimes (Supplementary Table S1). 


\subsection{Berry Skin Phenylpropanoids}

The irrigation regime affect both anthocyanin and flavonol derivatives and enzymatic activity. In detail, malvidin, total anthocyanin content and methoxylated to nonmethoxylated anthocyanin ratio were $+43 \%,+35 \%$, and $+16 \%$ higher in WS than in WW grapes. Among flavonols in berry skin, kaempferol derivatives were significantly higher $(+93 \%)$ in WS compared to WW vines. The activity of $\mathrm{F}^{\prime} 5^{\prime} \mathrm{OH}, 3^{\prime}-\mathrm{OMT}$, and $5^{\prime}$-OMT were similarly enhanced $(+24 \%,+23 \%$, and $+19 \%$, respectively) by water stress regime irrespective of $A$. nodosum treatments (Supplementary Table S2).

The anthocyanins detected in berry skin extracts were delphinidin-3-O-glucoside, cyanidin -3-O-glucoside, petunidin-3-O-glucoside, peonidin-3-O-glucoside, and malvidin-3-O-glucoside (Supplementary Figure S1A). At $t_{0}$, there were no significant differences in the anthocyanins content between $A$. nodosum treated and untreated plants in irrigation regimes (Figure 3). On the contrary, at $t_{1}$ and $t_{2}$, both in WW and WS vines, delphinidin-3-O-, petunidin-3-O-, cyanidin-3-O-, and peonidin-3-O-glucoside contents were significantly more abundant in SWE than CTRL berry skins (Figure $3 \mathrm{~A}, \mathrm{~B}, \mathrm{D}, \mathrm{E})$. Moreover, at $\mathrm{t}_{1}$, berry skin contents of malvidin and total anthocyanin were higher in SWE than in CTRL plants (Figure 3F), irrespective of the irrigation regime. The opposite trend was observed at $t_{2}$, when malvidin and total anthocyanin did not significantly differ in treated and untreated berry skins, in both water regimes.

In WW vines, the ratio of methoxylated to nonmethoxylated anthocyanins and the percentage of methoxylated anthocyanins/tot were both higher in CTRL than in SWE at $t_{1}$ and the amplitude of these ratios was larger at $t_{2}$ (Figure $\left.4 A, B\right)$. In WS vines, the methoxylated to nonmethoxylated anthocyanins ratio was higher in CTRL respect to SWE both at $t_{1}$ and $t_{2}$ (Figure $4 A$ ), whereas the percentage of methoxylated anthocyanins was unaffected by A. nodosum treatments in WS vines (Figure 4B).

At both sampling times and irrigation regimes, SWE berry skins presented a relevant increment in hydroxycinnamic acids (Figure 5A) and total phenolics (Figure 5D) content compared to CTRL counterparts.

The content of quercetin derivatives was more than two-fold higher in treated respect to untreated berry skins in both WW and WS vines at $t_{2}$. This difference was found also at $t_{1}$, but only in WS vines (Figure 5B). The opposite was observed for kaempferol derivatives (Figure 5C), that did not show significant changes at every sampling time and were marginally affected by the A.nodosum treatments only in WS vines, with higher values in SWE than in CTRL at $t_{2}$.

The enzymatic activities of $\mathrm{F}^{\prime} 5^{\prime} \mathrm{OH}, 3^{\prime}-\mathrm{OMT}$, and $5^{\prime}$-OMT are reported in Table 3.

Both in WW and WS vines, A. nodosum treatments did not affect $\mathrm{F}^{\prime}{ }^{\prime}{ }^{\prime} \mathrm{OH}$ enzymatic activity at $\mathrm{t}_{1}$, while decreasing its activity at $t_{2}$, leading to lower values in SWE than in CTRL vines.

Table 3. Enzymatic activities computed as ratios of anthocyanin amounts in berry skin of $V$. vinifera treated with A. nodosum extract (SWE) and untreated plants (CTRL), under two irrigation regimes (WW, well-watered; WS, water stressed).

\begin{tabular}{|c|c|c|c|c|c|c|c|}
\hline \multirow[b]{2}{*}{$\begin{array}{l}\text { Irrig. } \\
\text { Regime }\end{array}$} & \multirow[b]{2}{*}{$\begin{array}{l}\text { Samp. } \\
\text { Time }\end{array}$} & \multicolumn{2}{|c|}{ F $3^{\prime} 5^{\prime} \mathrm{OH}$ Activity } & \multicolumn{2}{|c|}{ 3'-OMT Activity } & \multicolumn{2}{|c|}{ 5'-OMT Activity } \\
\hline & & CTRL & SWE & CTRL & SWE & CTRL & SWE \\
\hline \multirow{3}{*}{ WW } & $t_{0}$ & $3.93 \pm 0.05 a$ & $4.40 \pm 0.05 \mathrm{a}$ & $6.84 \pm 0.7 \mathrm{a}$ & $6.45 \pm 0.7 \mathrm{a}$ & $9.30 \pm 0.6 \mathrm{a}$ & $10.04 \pm 0.7 \mathrm{a}$ \\
\hline & $t_{1}$ & $2.86 \pm 0.40 \mathrm{a}$ & $3.69 \pm 0.56 \mathrm{a}$ & $8.08 \pm 0.6 \mathrm{a}$ & $6.88 \pm 1.4 b$ & $14.12 \pm 1.4 \mathrm{a}$ & $10.48 \pm 0.4 b$ \\
\hline & $t_{2}$ & $5.09 \pm 0.15 \mathrm{a}$ & $2.42 \pm 0.09 \mathrm{~b}$ & $11.73 \pm 0.9 \mathrm{a}$ & $11.31 \pm 2.2 \mathrm{a}$ & $29.23 \pm 3.9 \mathrm{a}$ & $9.60 \pm 3.2 \mathrm{~b}$ \\
\hline \multirow{3}{*}{ WS } & $t_{0}$ & $5.42 \pm 0.07 \mathrm{a}$ & $5.42 \pm 0.07 \mathrm{a}$ & $10.30 \pm 1.9 \mathrm{a}$ & $10.30 \pm 1.9 \mathrm{a}$ & $12.34 \pm 0.4 \mathrm{a}$ & $12.20 \pm 0.4 \mathrm{a}$ \\
\hline & $t_{1}$ & $4.29 \pm 0.15 \mathrm{a}$ & $4.13 \pm 0.14 \mathrm{a}$ & $8.47 \pm 0.3 \mathrm{a}$ & $6.69 \pm 1.6 b$ & $16.00 \pm 1.4 \mathrm{a}$ & $13.57 \pm 1.1 b$ \\
\hline & $t_{2}$ & $4.55 \pm 0.06 \mathrm{a}$ & $3.89 \pm 0.31 b$ & $14.02 \pm 0.3 \mathrm{a}$ & $13.25 \pm 0.9 \mathrm{a}$ & $22.36 \pm 2.0 \mathrm{a}$ & $22.27 \pm 4.9 \mathrm{a}$ \\
\hline
\end{tabular}

Means $( \pm \mathrm{SE}, n=10)$ followed by distinct letters within the same parameter and row are significantly different according to the LSD test $(p \leq 0.05)$. Measurements were conducted at $t_{0}, t_{1}$ and $t_{2}$. 
Moreover, SWE vines showed lower $3^{\prime}$-OMT activity than CTRL only at $\mathrm{t}_{1}$, in both irrigation regimes. The $5^{\prime}$-OMT enzymatic activity was also affected by $A$. nodosum treatments, that lowered $5^{\prime}$-OMT in WW treated vines at $t_{1}$ and $t_{2}$, and also in WS vines at $t_{1}$ (Table 3 ).

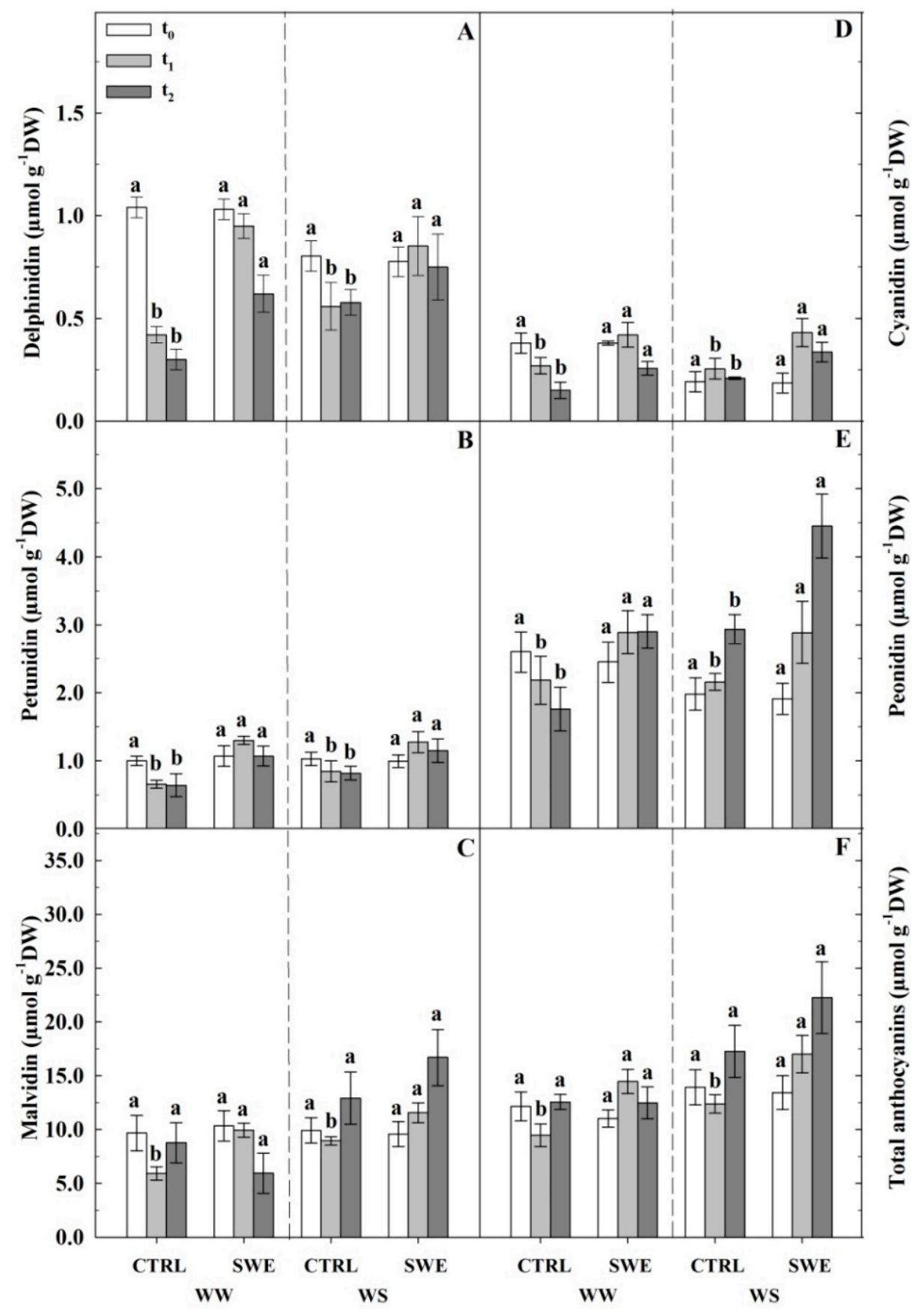

Figure 3. Berry skin individual anthocyanin amounts in $V$. vinifera treated with $A$. nodosum extract (SWE) and untreated plants (CTRL) under two irrigation regimes (WW, well-watered; WS, water stressed). (A) Delphinidin, (B) Petunidin, (C) Malvidin, (D) Cyanidin, (E) Peonidin, and (F) Total anthocyanin contents. Means $( \pm \mathrm{SE}, n=5)$ followed by distinct letters within the same water regime and sampling time are significantly different according to the LSD test $(p \leq 0.05)$. Measurements were conducted at $\mathrm{t}_{0}$ (white bar), $\mathrm{t}_{1}$ (grey bar), and $\mathrm{t}_{2}$ (dark grey bar). 

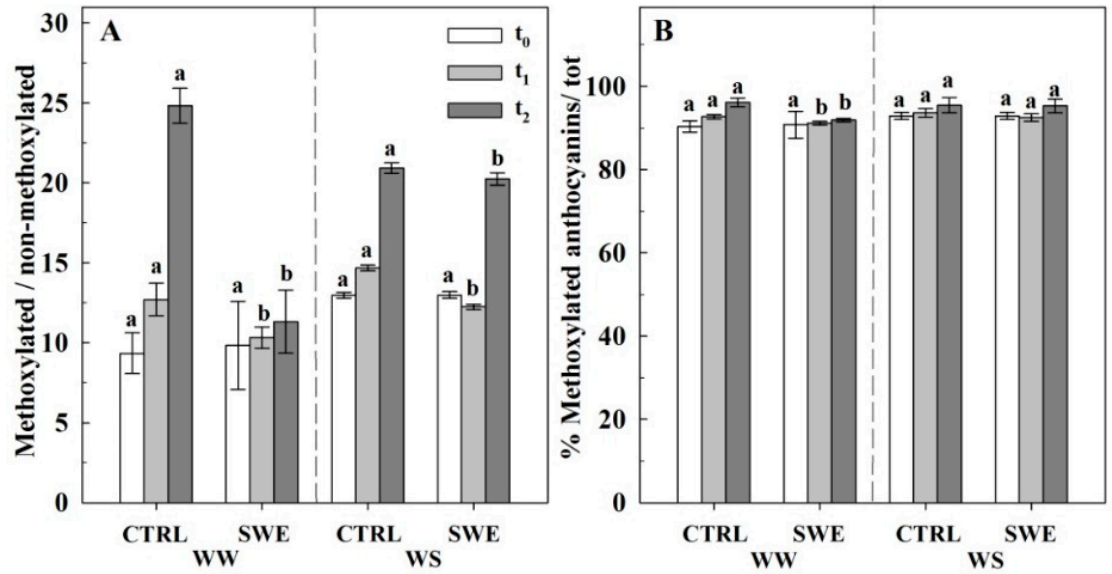

Figure 4. Berry skin anthocyanins methoxylation in $V$. vinifera treated with $A$. nodosum extract (SWE) and untreated plants (CTRL) under two irrigation regimes (WW, well-watered; WS, water stressed). (A) Methoxylated/non-methoxylated anthocyanins ratio; (B) \% of methoxylated anthocyanins on total anthocyanin content. Means $( \pm \mathrm{SE}, n=5)$ followed by distinct letters within the same water regime and sampling time are significantly different according to the LSD test $(p \leq 0.05)$. Measurements were conducted at $\mathrm{t}_{0}$ (white bar), $\mathrm{t}_{1}$ (grey bar), and $\mathrm{t}_{2}$ (dark grey bar)

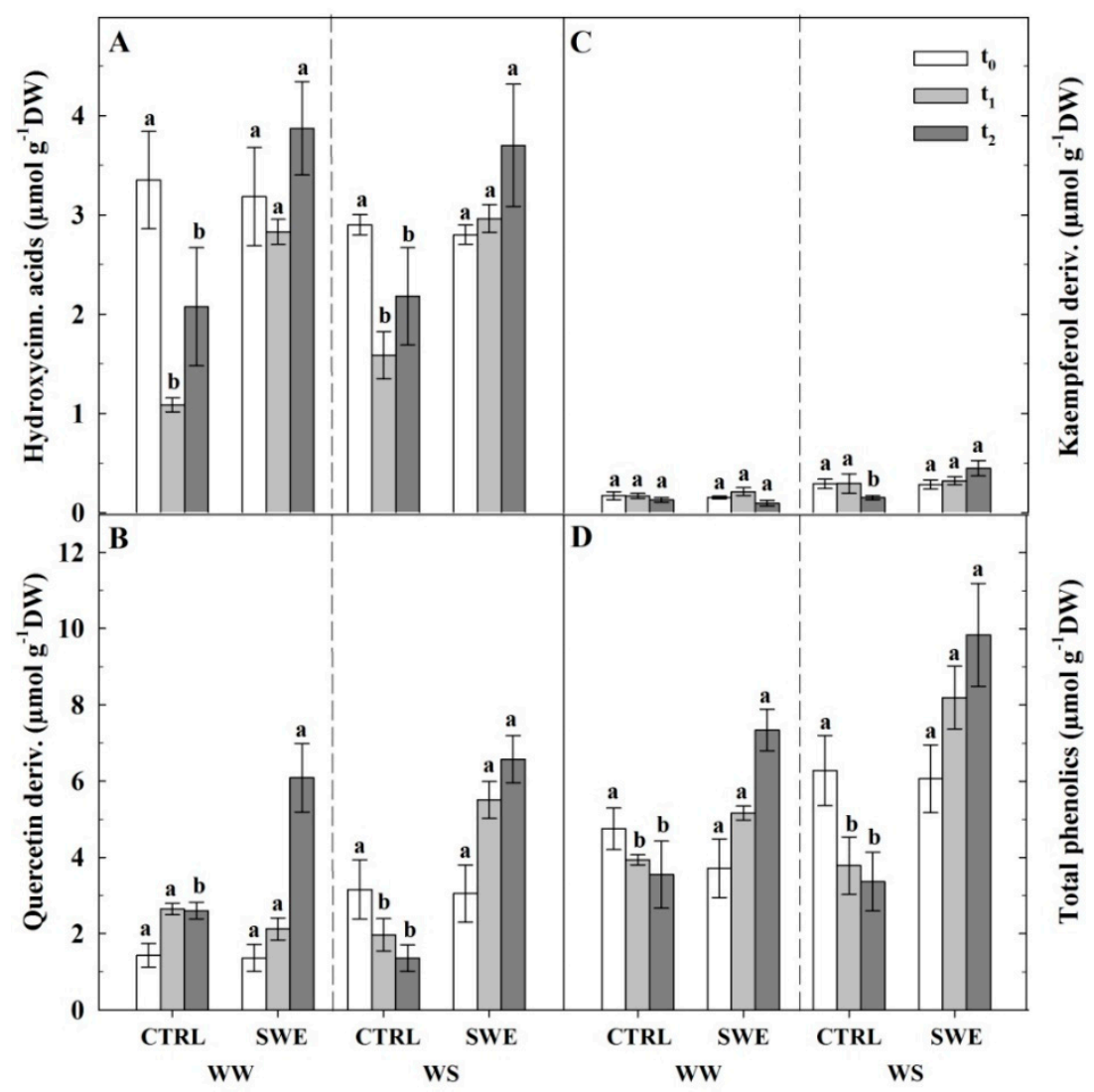

Figure 5. Berry skin hydroxycinnamic acids and flavonols in $V$. vinifera treated with A. nodosum extract (SWE) and untreated plants (CTRL) under two irrigation regimes (WW, well-watered; WS, water stressed). (A) Hydroxycinnamic acids, (B) Quercetin derivatives, (C) Kaempferol derivatives, and (D) Total phenolic contents. Means $( \pm \mathrm{SE}, n=5)$ followed by distinct letters within the same water regime and sampling time are significantly different according to the LSD test $(p \leq 0.05)$. Measurements were conducted at $\mathrm{t}_{0}$ (white bar), $\mathrm{t}_{1}$ (grey bar), and $\mathrm{t}_{2}$ (dark grey bar). 


\section{Discussion}

\subsection{Consequences of Water Deficit on Pinot Noir Physiology and Berry Skin Anthocyanin Content}

Important changes in physiological responses are typically observed in Vitis vinifera under different levels of water stress, such as decrease of leaf stomatal conductance and photosynthetic rate $[1,11,56]$, which often affect berry sugar accumulation [57-59]. A moderate restriction of water supply improves the quality of red wines by achieving optimal sugar levels, due to the competition for carbon assimilates between berry ripening and shoot growth and to a lower sugar concentration in berries because of increased berry size [60]. When the limitation in vine water uptake is severe, the stomatal closure restricts photosynthesis, reducing berry weight, accumulation of sugars, and yield [2,61,62]. In our study, as expected, $P_{n}, g_{s}, \Psi_{\text {pd }}, \Psi_{\text {stem, }}$ and RWC were significantly reduced by drought in WS vines with respect to WW ones; moreover, low water availability decreased titratable acidity, $\mathrm{pH}$, berry weight, and, consequently, cluster weight and yield. However, water availability did not significantly affect berry sugar accumulation. This result is in agreement with the results observed by Poni et al. [63] on Pinot noir cv. in pot conditions, whereas the same cultivar showed a decrease in berry sugar content induced by high soil water availability compared to water stresses plants in field conditions [64]. This discrepancy between pot and field trials can be linked to the space limitation for root development impaired by the pot, which does not occur in the open field. This restraint may have restricted carbohydrates reserves stored in grapevine roots, which are known to contribute to berry sugar accumulation, after translocation to berries, by hydrolyzation of the starch into soluble sugars [65,66].

At biochemical level, an increment in malvidin and in total anthocyanin contents was found in water stressed vines, suggesting that low water availability drove a major flux of carbon in the anthocyanin pathway, particularly towards more stable malvidin-based derivatives [67]. This effect partly compensated the reduction in anthocyanin biosynthesis caused by the reduction in $P_{n}$ because of stomatal closure [23]. Moreover, in WS berry skins, we observed an increase in the methoxylated to nonmethoxylated anthocyanin ratio, confirming that water stress boosts methoxylation, thus anthocyanin stability, as an adaptive strategy to adverse climatic conditions, like heat stress and high radiation load $[23,68,69]$.

\subsection{Timing of Action of A. nodosum Extract in Improving Plant Physiological Performance and Water Relations}

Our results confirm that $A$. nodosum treatments during the last stages of berry development allow to improve leaf gas exchanges of $V$. vinifera and show for the first time that the beneficial effect of these treatments can be observed under water stress conditions. Indeed, in SWE vines subjected to water stress, despite the occurrence of a severe reduction in stomatal conductance $\left(g_{s}<50 \mathrm{mmol}\right.$ $\mathrm{H}_{2} \mathrm{O} \mathrm{m}^{-2} \mathrm{~s}^{-1}$ ) [1,11], diffusional limitation to photosynthesis were less pronounced compared to CTRL vines, thus resulting in a higher WUE. The effectiveness of $A$. nodosum treatment on vine physiology could be also discerned at $t_{1}$ under water stress conditions, since SWE plants maintained higher water potentials ( $\left.\Psi_{\mathrm{pd}}, \Psi_{\text {stem }}\right)$ than in CTRL vines. At this sampling point, the high air temperature induced a strong decrease in RWC; however, this decline was much more evident in nontreated plants, supporting the hypothesis of a positive effect of $A$. nodosum in preventing excessive leaf dehydration [70]. The effect of the treatments on plant water status persisted and was intensified with water stress progression. Indeed, at $t_{2}$, SWE vines showed a better $K_{\text {plant }}$ than CTRL vines. The maintenance of an adequate $K_{\text {plant }}$ may have allowed SWE leaf to prevent stomatal closure and, consequently, an excessive restriction in carbon gain [71]. In addition, since the decline in $\mathrm{K}_{\text {plant }}$ is associated with hydraulic dysfunction, our results suggest that SWE leaf are less vulnerable to conduit embolism and collapse [56,72,73].

This effect could be particularly important in Pinot noir cv. which adopts an anisohydric strategy to cope with water stress, since anisohydric species are usually reported as more vulnerable to hydraulic failure [74]. The typical anisohydric behavior is evident from the slope (0.902) of the linear correlation between predawn and midday leaf water potential, which is close to 1 for extreme anisohydric 
species [75]. Our result suggests that A. nodosum treatment could help maintaining a better water status of the plant preventing excessive stomatal closure without affecting the plant hydraulic strategy. The strong anisohydric behavior with great variations in leaf gas exchange and water relations during water stress progression could have been exacerbated by pot conditions, which imply the impossibility to access deeper soil water as in field conditions, where minor reductions in $\Psi_{\text {leaf }}$ are usually observed [76].

However, controlled water stress conditions allowed us to validate the effect of A. nodosum treatments on vine physiology previously documented in the field trial [46] and to highlight a timing of action of these treatments. Indeed, the effects of A. nodosum treatments resulted particularly effective over the last part of the growing season, allowing treated plants to cope better with prolonged stress and leaf senescence. We hypothesize that the amino acids of the A.nodosum extract, in particular proline, which is involved in drought tolerance acting both as cytoplasmic osmolyte and as ROS-scavenging compound [36,37], may have played a key role in the enhancement of physiological performances and the maintenance of optimal water status. This mechanism could be particularly important under atmospheric stress conditions in adult leaves, which, differently from apical young tissues, are less able to accumulate actively solutes during the day and are subjected to oscillations of RWC [77]. These changes induced by $A$. nodosum treatments on plant physiology did not have relevant consequences on berry ripening, indeed the evolution of total sugars, titratable acidity, and $\mathrm{pH}$ were unaffected by A. nodosum treatments. This observation is in agreement with the results obtained by Frioni et al. [49,50], but it is somewhat contrasting with the previous observations conducted in field conditions [46]. This discrepancy could be related to multiple factors, such as biological (cultivar, rootstock), methodological (pot or field studies), and environmental (season) factors, which may influence grape ripening pattern [78].

In addition, berry weight and vine productivity (data not shown) were not affected by medium-late A. nodosum extract applications. Conversely, biostimulant applications during early stages of berry development could lead to an improvement in berry weight and vine yield, as formerly mentioned for table grape [41-44].

\subsection{A. nodosum Treatments Influenced the Biosynthesis of Berry Skin Anthocyanins Irrespective of Irrigation Regime}

The A. nodosum treatment induced higher content of delphinidin, petunidin, cyanidin, and peonidin derivatives under both irrigation regimes both at $t_{1}$ and at $t_{2}$. This treatment-induced increment of anthocyanins in Vitis vinifera is consistent in both pot and field conditions $[46,50]$ and is reported also in other species [79-81]. In addition, we observed a reduction of the methoxylated to nonmethoxylated anthocyanin ratio and of the percentage of methoxylated anthocyanins on total anthocyanins in berry skin induced by $A$. nodosum treatments. This result is also supported by enzymatic activities, which generally showed lower 3'-OMT and 5'-OMT values in SWE than CTRL grapes, thus a higher enzymatic activity towards the biosynthesis of nonmethoxylated anthocyanins (cyanidin and delphinidin) than methoxylated ones (peonidin and malvidin) following A. nodosum treatment. The reduced investment in methoxylated anthocyanins was observed both under well-watered and water stress conditions, differently from the results conducted without the application of biostimulants by Castellarin et al. [82], which showed a more effective increase of expression of some enzymes involved in the biosynthesis of tri-hydroxylated anthocyanins as a consequence of water stress application. On this basis, we hypothesize that the activity of flavonoid $3^{\prime}$-hydroxylases $\left(\mathrm{F}^{\prime}{ }^{\prime} \mathrm{H}\right)$ enzyme may have been stimulated by $A$. nodosum treatments, hence activating the synthesis of cyanidin-based anthocyanins, rather than inducing the activity of $\mathrm{F}^{\prime}{ }^{\prime} 5^{\prime} \mathrm{OH}$ enzyme and the delphinidin parallel branch $[35,83]$. Indeed, the treatment may reduce the investment in more stable methoxylated anthocyanins, commonly stored in berries to confer protection against severe climate conditions [84,85]. In addition, under both irrigation regimes, we observed an increase in flavonols and hydroxycinnamic acids in berry skin after A. nodosum treatments. In particular, the increment in quercetin derivatives, which are di-hydroxy B-ring-substituted flavonols and confer protection against reactive oxygen species, may concur to 
wine color by acting as copigmentation factors [86], positively affecting wine color stability [87]. The biosynthesis of flavonols and anthocyanins in the berry are mutually related, because both classes of compounds derive from the same metabolic pathway [19]: F3' $\mathrm{H}$ and $\mathrm{F}^{\prime}{ }^{\prime} 5^{\prime} \mathrm{OH}$ activate both the biosynthesis of cyanidin- and delphinidin-based anthocyanins, as well as of quercetin and myricetin derivatives, respectively [88]. Quercetin derivatives were abundantly detected in our berry samples, whereas myricetin derivatives were recognized only in traces. These findings may further support the hypothesis that $A$. nodosum treatments selectively promoted $\mathrm{F}^{\prime}{ }^{\prime} \mathrm{H}$ enzyme activation, instead of $\mathrm{F}^{\prime} 5^{\prime} \mathrm{OH}$, thus the biosynthesis of di-hydroxy flavonoids in place of their tri-hydroxy B-ring-substituted. These metabolic and enzymatic results perfectly match recent findings on A. nodosum capability of inducing the expression of specific genes involved in secondary metabolites pathways in Vitis vinifera after veraison [50], also hypothesized before by other authors $[35,83]$. On this basis, we can speculate that the A. nodosum extract may have helped to mitigate environmental stress conditions by affecting the activation of specific genes related to the biosynthesis of less carbon expensive anthocyanins and flavonols [89]. In fact, the early accumulation of these antioxidant compounds in the berry skin may have offered protection to treated vines against environmental conditions [90], as demonstrated by higher physiological and hydraulic performances observed at $t_{2}$.

\section{Conclusions}

The increments of leaf gas exchanges and water potentials following A. nodosum treatments were previously reported in other species. However, this research provides new evidences that A. nodosum treatments may affect both eco-physiological traits and berry skin metabolism of Pinot noir cv., conferring a better ability to counteract low water availability during post-veraison stages.

In summary, $A$. nodosum enhanced vines water stress tolerance by improving leaf water status and hydraulic conductance, thus maintaining optimal gas exchanges. Furthermore, in both water regimes, the biochemistry of berry skin was profoundly affected by A. nodosum treatments. We demonstrate a selectivity action of these treatments on lowering the enzyme activities involved in the synthesis of methoxylated anthocyanins in treated vines. Moreover, $A$. nodosum may have a significant effect on wine color stability, increasing the content of antioxidant flavonoids (quercetin derivatives) involved in copigmentation in berry skin. Overall, the data obtained from this experiment indicated that the effects and the protocol of application of this $A$. nodosum extract have been validated, and that late treatments with $A$. nodosum can be a practical approach for wineries to improve the eco-physiology of $V$. vinifera and to positively affect berry biochemical composition.

Supplementary Materials: The following are available online at http://www.mdpi.com/2076-3417/10/13/4473/s1. Figure S1: HPLC-DAD chromatograms of hydroalcholic extract of berry skins. Figure S2: Relationship between pre-dawn ( $\left.\Psi_{\mathrm{pd}}\right)$ and midday $\left(\Psi_{\text {leaf }}\right)$ water potential. Figure S3: Experimental site pictures. Table S1: Total sugars, titratable acidity (TA), $\mathrm{pH}$ and berry weight. Table S2: Two-way ANOVA $(p<0.05)$ for biochemical parameters in berry skin and enzymatic activities. Table S3: Shapiro-Wilk's test $(p<0.05)$ (George and Mallery, 2010) results for each parameter.

Author Contributions: The experiment was designed and arranged by G.B.M., L.S., and C.B., L.S. and E.C. sprayed A. nodosum extract, executed gas exchange and water potentials measurements, and picked berry samples. L.S. and E.C. also processed data and carried out statistical analysis. L.S. and C.B. accomplished the phenylpropanoids HPLC analysis. L.S. and C.B. wrote the original draft, which was edited and improved by P.S. and G.B.M. All authors have read and agreed to the published version of the manuscript.

Funding: This research did not receive any specific grant from funding agencies in the public, commercial, or not-for-profit sectors.

Acknowledgments: Authors acknowledge Dott. Alessandra Zombardo and Dott. Sergio Puccioni from CREA-VE (Italy) for experiment location general arrangement and irrigation supply.

Conflicts of Interest: The authors declare no conflict of interest. 


\section{References}

1. Cifre, J.; Bota, J.; Escalona, J.M.; Medrano, H.; Flexas, J. Physiological tools for irrigation scheduling in grapevine (Vitis vinifera L.). An open gate to improve water-use efficiency? Agric. Ecosyst. Environ. 2005, 106, 159-170. [CrossRef]

2. Chaves, M.M.; Santos, T.P.; Souza, C.D.; Ortuño, M.F.; Rodrigues, M.L.; Lopes, C.M.; Maroco, J.P.; Pereira, J.S. Deficit irrigation in grapevine improves water-use efficiency while controlling vigour and production quality. Ann. Appl. Biol. 2007, 150, 237-252. [CrossRef]

3. Schultz, H.R.; Jones, G.V. Climate induced historic and future changes in viticulture. J. Wine Res. 2010, 21, 137-145. [CrossRef]

4. Spinoni, J.; Naumann, G.; Vogt, J.; Barbosa, P. European drought climatologies and trends based on a multi-indicator approach. Glob. Planet. Chang. 2015, 127, 50-57. [CrossRef]

5. Schultz, H.R. Differences in hydraulic architecture account for near-isohydric and anisohydric behaviour of two field-grown Vitis vinifera L. cultivars during drought. Plant Cell Environ. 2003, 26, 1393-1405. [CrossRef]

6. Rogiers, S.Y.; Greer, D.H.; Hutton, R.J.; Landsberg, J.J. Does night-time transpiration contribute to anisohydric behaviour in a Vitis vinifera cultivar? J. Exp. Bot. 2009, 60, 3751-3763. [CrossRef] [PubMed]

7. Costa, J.M.; Ortuño, M.F.; Lopes, C.M.; Chaves, M.M. Grapevine varieties exhibiting differences in stomatal response to water deficit. Funct. Plant Biol. 2012, 39, 179-189. [CrossRef]

8. Tomás, M.; Medrano, H.; Escalona, J.M.; Martorell, S.; Pou, A.; Ribas-Carbó, M.; Flexas, J. Variability of water use efficiency in grapevines. Environ. Exp. Bot. 2014, 103, 148-157. [CrossRef]

9. Medrano, H.; Tomás, M.; Martorell, S.; Flexas, J.; Hernández, E.; Rosselló, J.; Bota, J. From leaf to whole-plant water use efficiency (WUE) in complex canopies: Limitations of leaf WUE as a selection target. Crop J. 2015, 3, 220-228. [CrossRef]

10. Bota, J.; Tomás, M.; Flexas, J.; Medrano, H.; Escalona, J.M. Differences among grapevine cultivars in their stomatal behavior and water use efficiency under progressive water stress. Agric. Water Manag. 2016, 164, 91-99. [CrossRef]

11. Flexas, J.; Bota, J.; Cifre, J.; Mariano Escalona, J.; Galmés, J.; Gulías, J.; Riera, D. Understanding down-regulation of photosynthesis under water stress: Future prospects and searching for physiological tools for irrigation management. Ann. Appl. Biol. 2004, 144, 273-283. [CrossRef]

12. Flexas, J.; Medrano, H. Drought-inhibition of photosynthesis in $\mathrm{C}_{3}$ plants: Stomatal and non-stomatal limitations revisited. Ann. Bot. 2002, 89, 183-189. [CrossRef]

13. Sadras, V.O.; Petrie, P.R. Climate shifts in south-eastern Australia: Early maturity of Chardonnay, Shiraz and Cabernet Sauvignon is associated with early onset rather than faster ripening. Aust. J. Grape Wine Res. 2011, 17, 199-205. [CrossRef]

14. Petrie, P.R.; Sadras, V.O. Advancement of grapevine maturity in Australia between 1993 and 2006: Putative causes, magnitude of trends and viticultural consequences. Aust. J. Grape Wine Res. 2008, 14, 33-45. [CrossRef]

15. Teixeira, A.; Eiras-Dias, J.; Castellarin, S.D.; Gerós, H. Berry phenolics of grapevine under challenging environments. Int. J. Mol. Sci. 2013, 14, 18711-18739. [CrossRef]

16. Sadras, V.O.; Moran, M.A. Elevated temperature decouples anthocyanins and sugars in berries of Shiraz and Cabernet Franc. Aust. J. Grape Wine Res. 2012, 18, 115-122. [CrossRef]

17. Adams, D.O. Phenolics and ripening in grape berries. Am. J. Enol. Vitic. 2006, 57, 246-256.

18. Waterhouse, A.L. Wine phenolics. Ann. N. Y. Acad. Sci. 2002, 957, 21-36. [CrossRef]

19. Mattivi, F.; Guzzon, R.; Vrhovsek, U.; Stefanini, M.; Velasco, R. Metabolite profiling of grape: Flavonols and anthocyanins. J. Agric. Food Chem. 2006, 54, 7692-7702. [CrossRef]

20. Silva, L.R.; Queiroz, M. Bioactive compounds of red grapes from Dão region (Portugal): Evaluation of phenolic and organic profile. Asian Pac. J. Trop. Biomed. 2016, 6, 315-321. [CrossRef]

21. Ortega-Regules, A.; Romero-Cascales, I.; López-Roca, J.M.; Ros-García, J.M.; Gómez-Plaza, E. Anthocyanin fingerprint of grapes: Environmental and genetic variations. J. Sci. Food Agric. 2006, 86, 1460-1467. [CrossRef]

22. Castellarin, S.D.; Di Gaspero, G. Transcriptional control of anthocyanin biosynthetic genes in extreme phenotypes for berry pigmentation of naturally occurring grapevines. BMC Plant Biol. 2007, 7, 46. [CrossRef] 
23. Zarrouk, O.; Brunetti, C.; Egipto, R.; Pinheiro, C.; Genebra, T.; Gori, A.; Lopes, C.M.; Tattini, M.; Chaves, M.M. Grape ripening is regulated by deficit irrigation/elevated temperatures according to cluster position in the canopy. Front. Plant Sci. 2016, 7, 1640. [CrossRef] [PubMed]

24. Ertani, A.; Nardi, S.; Altissimo, A. Long-term research activity on the biostimulant properties of natural origin compounds. In Proceedings of the I World Congress on the Use of Biostimulants in Agriculture, Strasbourg, France, 26-29 November 2012; Volume 1009, pp. 181-187.

25. Posmyk, M.M.; Szafrańska, K. Biostimulators: A new trend towards solving an old problem. Front. Plant Sci. 2016, 7, 748. [CrossRef]

26. Yakhin, O.I.; Lubyanov, A.A.; Yakhin, I.A.; Brown, P.H. Biostimulants in plant science: A global perspective. Front. Plant Sci. 2017, 7, 2049. [CrossRef]

27. Craigie, J.S. Seaweed extract stimuli in plant science and agriculture. J. Appl. Phycol. 2011, 23, 371-393. [CrossRef]

28. Sangha, J.S.; Kelloway, S.; Critchley, A.T.; Prithiviraj, B. Seaweeds (macroalgae) and their extracts as contributors of plant productivity and quality: The current status of our understanding. Adv. Bot. Res. 2014, 71, 189-219.

29. De Saeger, J.; Van Praet, S.; Vereecke, D.; Park, J.; Jacques, S.; Han, T.; Depuydt, S. Toward the molecular understanding of the action mechanism of Ascophyllum nodosum extracts on plants. J. Appl. Phycol. 2020, 32, 573-597. [CrossRef]

30. Richardson, A.D.; Aikens, M.; Berlyn, G.P.; Marshall, P. Drought stress and paper birch (Betula papyrifera) seedlings: Effects of an organic biostimulant on plant health and stress tolerance, and detection of stress effects with instrument-based, noninvasive methods. J. Arboric. 2004, 30, 52-61.

31. Spann, T.M.; Little, H.A. Application of commercial extract of the brown seaweed Ascophyllum nodosum increases drought tolerance in container-grown 'Hamlin' Sweet Orange nursery trees. HortScience 2011, 46, 577-582. [CrossRef]

32. Elansary, H.O.; Skalicka-Woźniak, K.; King, I.W. Enhancing stress growth traits as well as phytochemical and antioxidant contents of Spiraea and Pittosporum under seaweed extract treatments. Plant Physiol. Bioch. 2016, 105, 310-320. [CrossRef]

33. Martynenko, A.; Shotton, K.; Astatkie, T.; Petrash, G.; Fowler, C.; Neily, W.; Critchley, A.T. Thermal imaging of soybean response to drought stress: The effect of Ascophyllum nodosum seaweed extract. Springerplus 2016, 5, 1393. [CrossRef]

34. Elansary, H.O.; Yessoufou, K.; Abdel-Hamid, A.M.; El-Esawi, M.A.; Ali, H.M.; Elshikh, M.S. Seaweed extracts enhance Salam turfgrass performance during prolonged irrigation intervals and saline shock. Front. Plant Sci. 2017, 8, 830. [CrossRef]

35. Santaniello, A.; Scartazza, A.; Gresta, F.; Loreti, E.; Biasone, A.; Di Tommaso, D.; Piaggesi, A.; Perata, P. Ascophyllum nodosum seaweed extract alleviates drought stress in Arabidopsis by affecting photosynthetic performance and related gene expression. Front. Plant Sci. 2017, 8, 1362. [CrossRef]

36. Khan, W.; Rajirath, U.P.; Subramanian, S.; Jithesh, M.N.; Rayorath, P.; Hodges, D.M.; Critchley, A.T.; Craigie, J.S.; Norrie, J.; Prithiviraj, B. Seaweed extracts as biostimulants of plant growth and development. J. Plant Growth Regul. 2009, 28, 386-399. [CrossRef]

37. Di Stasio, E.; Van Oosten, M.J.; Silletti, S.; Raimondi, G.; dell'Aversana, E.; Carillo, P.; Maggio, A. Ascophyllum nodosum-based algal extracts act as enhancers of growth, fruit quality, and adaptation to stress in salinized tomato plants. J. Appl. Phycol. 2018. [CrossRef]

38. Berlyn, G.P.; Russo, R.O. The use of organic biostimulants in nitrogen fixing trees. Nitrogen Fix. Tree Res. Rep. 1990, 8, 78-80.

39. Blunden, G.; Gordon, S.M.; Smith, B.E.; Fletcher, R.L. Quaternary ammonium compounds in species of the Fucaceae (Phaeophyceae) from Britain. Br. Phycol. J. 1985, 20, 105-108. [CrossRef]

40. Laetitia, A.; Fauchon, M.; Blanc, N.; Hauchard, D.; ArGall, E. Phenolic compounds in the brown seaweed Ascophyllum nodosum: Distribution and radical-scavenging activities. Phytochem. Anal. 2010, 21, 399-405.

41. Norrie, J.; Branson, T.; Keathley, P.E. Marine plant extracts impact on grape yield and quality. Acta Hortic. 2002, 594, 315-319. [CrossRef]

42. Colapietra, M.; Alexander, A. Effect of foliar fertilization on yield and quality of table grapes. Acta Hortic. 2006, 721, 213-218. [CrossRef] 
43. Norrie, J.; Keathley, J.P. Benefits of Ascophyllum nodosum marine-plant extract applications to 'Thompson Seedless' grape production. Acta Hortic. 2006, 727, 243-247. [CrossRef]

44. Kok, D.; Bal, E.; Celik, S.; Ozer, C.; Karauz, A. The influences of different seaweed doses on table quality characteristics of cv. trakya ilkeren (Vitis vinifera). Bulg. J. Agric. Sci. 2010, 16, 429-435.

45. Mancuso, S.; Briand, X.; Mugnai, S.; Azzarello, E. Marine bioactive substances (IPA Extract) improve foliar ion uptake and water stress tolerance in potted "Vitis vinifera" plants. Adv. Hortic. Sci. 2006, 20, 156-161.

46. Salvi, L.; Brunetti, C.; Cataldo, E.; Niccolai, A.; Centritto, M.; Ferrini, F.; Mattii, G.B. Effects of Ascophyllum nodosum extract on Vitis vinifera: Consequences on plant physiology, grape quality and secondary metabolism. Plant Physiol. Biochem. 2019, 139, 21-32. [CrossRef]

47. Khan, A.S.; Ahmad, B.; Jaskani, M.J.; Ahmad, R.; Malik, A.U. Foliar application of mixture of amino acids and seaweed (Ascophylum nodosum) extract improve growth and physicochemical properties of grapes. Int. J. Agric. Biol. 2012, 14, 383-388.

48. Sabir, A.; Yazar, K.; Sabir, F.; Kara, Z.; Yazici, M.A.; Goksu, N. Vine growth, yield, berry quality attributes and leaf nutrient content of grapevines as influenced by seaweed extract (Ascophyllum nodosum) and nanosize fertilizer pulverization. Sci. Hortic. 2014, 175, 1-8. [CrossRef]

49. Frioni, T.; Sabbatini, P.; Tombesi, S.; Norrie, J.; Poni, S.; Gatti, M.; Palliotti, A. Effects of a biostimulant derived from the brown seaweed Ascophyllum nodosum on ripening dynamics and fruit quality of grapevines. Sci. Hortic. 2018, 232, 97-106. [CrossRef]

50. Frioni, T.; Tombesi, S.; Quaglia, M.; Calderini, O.; Moretti, C.; Poni, S.; Palliotti, A. Metabolic and transcriptional changes associated with the use of Ascophyllum nodosum extracts as tools to improve the quality of wine grapes (Vitis vinifera cv. Sangiovese) and their tolerance to biotic stress. J. Sci. Food Agric. 2019, 99, 6350-6363. [CrossRef]

51. Priori, S.; Barbetti, R.; L'Abate, G.; Bucelli, P.; Storchi, P.; Costantini, E.A.C. Natural terroir unit, Siena Province, Tuscany. J. Maps 2014, 10, 466-477. [CrossRef]

52. Palliotti, A.; Tombesi, S.; Frioni, T.; Famiani, F.; Silvestroni, O.; Zamboni, M.; Poni, S. Morpho-structural and physiological response of container-grown Sangiovese and Montepulciano cvv. (Vitis vinifera) to re-watering after a pre-veraison limiting water deficit. Funct. Plant Biol. 2014, 41, 634-647. [CrossRef] [PubMed]

53. Chaves, M.M.; Zarrouk, O.; Francisco, R.; Costa, J.M.; Santos, T.; Regalado, A.P.; Rodrigues, M.L.; Lopes, C.M. Grapevine under deficit irrigation: Hints from physiological and molecular data. Ann. Bot. 2010, 105, 661-676. [CrossRef] [PubMed]

54. Maxwell, K.; Johnson, G.N. Chlorophyll fluorescence: A practical guide. J. Exp. Bot. 2000, 51, 659-668. [CrossRef] [PubMed]

55. Scholander, P.F.; Bradstreet, E.D.; Hemmingsen, E.A.; Hammel, H.T. Sap pressure in vascular plants. Science 1965, 148, 339-346. [CrossRef]

56. Lovisolo, C.; Perrone, I.; Carra, A.; Ferrandino, A.; Flexas, J.; Medrano, H.; Schubert, A. Drought-induced changes in development and function of grapevine (Vitis spp.) organs and in their hydraulic and non-hydraulic interactions at the whole-plant level: A physiological and molecular update. Funct. Plant Biol. 2010, 37, 98-116. [CrossRef]

57. Bravdo, B.; Hepner, Y.; Loinger, C.; Cohen, S.; Tabacman, H. Effect of irrigation and crop level on growth, yield and wine quality of Cabernet Sauvignon. Am. J. Enol. Vitic. 1985, 36, 132-139.

58. Dokoozlian, N.K.; Kliewer, W.M. Influence of light on grape berry growth and composition varies during fruit development. J. Am. Soc. Hortic. Sci. 1996, 121, 869-874. [CrossRef]

59. Greer, D.H.; Weston, C. Heat stress affects flowering, berry growth, sugar accumulation and photosynthesis of Vitis vinifera cv. Semillon grapevines grown in a controlled environment. Funct. Plant Biol. 2010, 37, 206-214. [CrossRef]

60. Van Leeuwen, C.; Tregoat, O.; Choné, X.; Bois, B.; Pernet, D.; Gaudillère, J.P. Vine water status is a key factor in grape ripening and vintage quality for red Bordeaux wine. How can it be assessed for vineyard management purposes. J. Int. Sci. Vigne Vin 2009, 43, 121-134. [CrossRef]

61. Dry, P.R.; Loveys, B.R. Grapevine shoot growth and stomatal conductance are reduced when part of the root system is dried. Vitis 1999, 38, 151-156.

62. Medrano, H.; Escalona, J.M.; Bota, J.; Gulias, J.; Flexas, J. Regulation of photosynthesis of $C_{3}$ plants in response to progressive drought: Stomatal conductance as a reference parameter. Ann. Bot. 2002, 89, 895-905. [CrossRef] 
63. Poni, S.; Lakso, A.N.; Turner, J.R.; Melious, R.E. The effects of pre-and post-veraison water stress on growth and physiology of potted Pinot Noir grapevines at varying crop levels. Vitis 1993, 32, 207-214.

64. Zufferey, V.; Spring, J.L.; Verdenal, T.; Dienes, A.; Belcher, S.; Lorenzini, F.; Viret, O. The influence of water stress on plant hydraulics, gas exchange, berry composition and quality of Pinot Noir wines in Switzerland. OENO One 2017, 51. [CrossRef]

65. Rossouw, G.C.; Smith, J.P.; Barril, C.; Deloire, A.; Holzapfel, B.P. Carbohydrate distribution during berry ripening of potted grapevines: Impact of water availability and leaf-to-fruit ratio. Sci. Hortic. 2017, 216, 215-225. [CrossRef]

66. Davies, C.; Robinson, S.P. Sugar accumulation in grape berries: Cloning of two putative vacuolar invertase cDNAs and their expression in grapevine tissues. Plant Physiol. 1996, 111, 275-283. [CrossRef]

67. Azuma, A.; Yakushiji, H.; Koshita, Y.; Kobayashi, S. Flavonoid biosynthesis-related genes in grape skin are differentially regulated by temperature and light conditions. Planta 2012, 236, 1067-1080. [CrossRef]

68. Gill, S.S.; Tuteja, N. Reactive oxygen species and antioxidant machinery in abiotic stress tolerance in crop plants. Plant Physiol. Biochem. 2010, 48, 909-930. [CrossRef]

69. Rai, A.C.; Singh, M.; Shah, K. Environmental stresses and transgenics: Role of ZFP (ZAT) gene in multiple stress tolerance in plants. Adv. Plant Physiol. 2012, 13, 197-232.

70. Van Oosten, M.J.; Pepe, O.; De Pascale, S.; Silletti, S.; Maggio, A. The role of biostimulants and bioeffectors as alleviators of abiotic stress in crop plants. Chem. Biol. Technol. Agric. 2017, 4, 5. [CrossRef]

71. Flexas, J.; Scoffoni, C.; Gago, J.; Sack, L. Leaf mesophyll conductance and leaf hydraulic conductance: An introduction to their measurement and coordination. J. Exp. Bot. 2013, 64, 3965-3981. [CrossRef]

72. Hubbard, R.M.; Bond, B.J.; Ryan, M.G. Evidence that hydraulic conductance limits photosynthesis in old Pinus ponderosa trees. Tree Physiol. 1999, 19, 165-172. [CrossRef] [PubMed]

73. Johnson, D.M.; Woodruff, D.R.; McCulloh, K.A.; Meinzer, F.C. Leaf hydraulic conductance, measured in situ, declines and recovers daily: Leaf hydraulics, water potential and stomatal conductance in four temperate and three tropical tree species. Tree Physiol. 2009, 29, 879-887. [CrossRef] [PubMed]

74. Martínez-Vilalta, J.; Garcia-Forner, N. Water potential regulation, stomatal behaviour and hydraulic transport under drought: Deconstructing the iso/anisohydric concept. Plant Cell Environ. 2017, 40, 962-976. [CrossRef] [PubMed]

75. Roman, D.T.; Novick, K.A.; Brzostek, E.R.; Dragoni, D.; Rahman, F.; Phillips, R.P. The role of isohydric and anisohydric species in determining ecosystem-scale response to severe drought. Oecologia 2015, 179, 641-654. [CrossRef]

76. Villalobos-González, L.; Muñoz-Araya, M.; Franck, N.; Pastenes, C. Controversies in the midday water potential regulation and stomatal behauvior might result by the environment, genotype and/or roostock: Evidence from Carménère and Syrah grapevine varieties. Front. Plant Sci. 2019, 10, 1522. [CrossRef]

77. Düring, H. Evidence for osmotic adjustment to drought in grapevines (Vitis vinifera L.). Vitis 2016, 23, 1-10.

78. Dokoozlian, N.K. Grape berry growth and development. In Raisin Production Manual; Agricultural and Natural Resources Publication: Oakland, CA, USA, 2000; Volume 3393, p. 30.

79. Kumari, R.; Kaur, I.; Bhatnagar, A.K. Effect of aqueous extract of Sargassum johnstonii Setchell \& Gardner on growth, yield and quality of Lycopersicon esculentum Mill. J. Appl. Phycol. 2011, 23, 623-633.

80. Fan, D.; Hodges, D.M.; Zhang, J.; Kirby, C.W.; Ji, X.; Locke, S.J.; Critchley, A.T.; Prithiviraj, B. Commercial extract of the brown seaweed Ascophyllum nodosum enhances phenolic antioxidant content of spinach (Spinacia oleracea L.) which protects Caenorhabditis elegans against oxidative and thermal stress. Food Chem. 2011, 124, 195-202. [CrossRef]

81. Lola-Luz, T.; Hennequart, F.; Gaffney, M. Effect on health promoting phytochemicals following seaweed application, in potato and onion crops grown under a low input agricultural system. Sci. Hortic. 2014, 170, 224-227. [CrossRef]

82. Castellarin, S.D.; Matthews, M.A.; Di Gaspero, G.; Gambetta, G.A. Water deficit accelerate ripening and induce change in gene expression regulating flavonoid biosynthesis in grape berries. Planta 2007, 227, 101-112. [CrossRef]

83. Jayaraman, J.; Norrie, J.; Punja, Z.K. Commercial extract from the brown seaweed A. nodosum reduces fungal diseases in greenhouse cucumber. J. Appl. Phycol. 2011, 23, 353-361. [CrossRef]

84. Jackman, R.L.; Smith, J.L. Anthocyanins and betalains. In Natural Food Colorants, 2nd ed.; Hendry, G.A.F., Houghton, J.D., Eds.; Chapman \& Hall: London, UK, 1996; pp. 244-309. 
85. He, F.; Mu, L.; Yan, G.L.; Liang, N.N.; Pan, Q.H.; Wang, J.; Reeves, M.J.; Duan, C.Q. Biosynthesis of anthocyanins and their regulation in colored grapes. Molecules 2010, 15, 9057-9191. [CrossRef] [PubMed]

86. Boulton, R. The copigmentation of anthocyanins and its role in the color of red wine: A critical review. Am. J. Enol. Vitic. 2001, 52, 67-87.

87. Romboli, Y.; Mangani, S.; Buscioni, G.; Granchi, L.; Vincenzini, M. Effect of Saccharomyces cerevisiae and Candida zemplinina on quercetin, vitisin A and hydroxytyrosol contents in Sangiovese wines. World J. Microbiol. Biotechnol. 2015, 31, 1137-1145. [CrossRef]

88. Jeong, S.T.; Goto-Yamamoto, N.; Hashizume, K.; Esaka, M. Expression of the flavonoid 3'-hydroxylase and flavonoid 3,5'-hydroxylase genes and flavonoid composition in grape (Vitis Vinifera). Plant Sci. 2006, 170, 61-69. [CrossRef]

89. Tarara, J.M.; Lee, J.; Spayd, S.E.; Scagel, C.F. Berry temperature and solar radiation alter acylation, proportion, and concentration of anthocyanin in Merlot grapes. Am. J. Enol. Vitic. 2008, 59, 235-247.

90. Griesser, M.; Weingart, G.; Schoedl-Hummel, K.; Neumann, N.; Becker, M.; Varmuza, K.; Forneck, A. Severe drought stress is affecting selected primary metabolites, polyphenols, and volatile metabolites in grapevine leaves (Vitis vinifera cv. Pinot noir). Plant Physiol. Biochem. 2015, 88, 17-26. [CrossRef]

(C) 2020 by the authors. Licensee MDPI, Basel, Switzerland. This article is an open access article distributed under the terms and conditions of the Creative Commons Attribution (CC BY) license (http://creativecommons.org/licenses/by/4.0/). 